\title{
Promoting Sustainable Development in Rural Communities: The Role of the University of Botswana
}

\author{
Flora Tladi-Sekgwama ${ }^{1} \&$ Gabo P. Ntseane ${ }^{2}$ \\ ${ }^{1}$ Department of Lifelong Learning and Community Development, University of Botswana, Gaborone, Botswana \\ Correspondence: Flora Tladi-Sekgwama, Department of Lifelong Learning and Community Development, \\ University of Botswana, Gaborone, Botswana
}

Received: November 13, 2019

Accepted: January 31, 2020 Online Published: March 10, 2020

doi:10.5539/sar.v9n2p74

URL: https://doi.org/10.5539/sar.v9n2p74

\begin{abstract}
Universities are better placed through their community engagement mandates to provide solutions for sustainable community livelihoods. The paper uses the case of the Community Based Natural Resource Management (CBNRM) strategy, regarded as both a conservation and rural development strategy in Botswana to demonstrate how a structured community engagement agenda can enable the University of Botswana to play a more impactful role in the successful implementation of nationally upheld development initiatives such as the CBNRM. Systems theory is applied to demonstrate the need for a university engagement strategy, working model, guide to CBNRM sustainable development activities and a framework for the maintenance of sustainable engagement partnerships. Literature review showed uncoordinated research activity in support of the CBNRM by different departments and institutes of the UB. While content analysis of the CBNRM draft policy objectives showed the UB being more impactful by focusing its community engagement on two modes: "sustainability partnerships" and "research committed to sustainability".
\end{abstract}

Keywords: community engagement, sustainable development, sustainability

\section{Introduction}

Sustainable development is a multidimensional process that requires all actors in the development process to collectively apply intelligence to maintain the long term productivity of the natural resources on which the individual, groups, and community livelihoods depend (Wallis and Wallis, 2005). The concept of sustainable development points at three types of capital, economic, social, and environmental, requiring good management skills by communities and development organizations. The process depends on community structures that are empowering and address the needs of the members (Batanovic et al., 2011). According to Payne (1997 in Chile, 2004), the objective of empowerment is social justice, a concept central to any practice of development. Empowerment targets confidence building to improve the self-concept of individuals in communities. Sustainability emerges out of skilful blending of diverse ideas and shared human experiences, objectives, knowledge, decisions, technology, and organization (Batanovic et al., 2011). Therefore, with sustainable development, empowerment should go beyond community skill development to embrace a lifelong learning environment that ensures all capacity building facets of a community. In fact, this is a transformation emphasized by the Sustainable Development Goals (SDGs) that is inclusive and gives community members a fair chance to lead a decent life (Kende-Robb, 2016).

Sustainability is a success when people understand what resources need sustaining, the purpose, and for whose purpose. This leads to trading off values, beliefs, facilitating a more collective and participatory approach to social change through sustainable use of resources (Chile, 2004; Schiele, 2005). One vital role a university would play in enabling sustainable development and the desired transformation is that of linking "endogenous and exogenous actors and their knowledge bases"; that is, linking the local communities with the external world (Atterton and Thompson, 2010: 127). According to Kimball and Thomas (2012), the ability to play an active role depends on a felt social responsibility by a university as an organization and the extent to which such an institution values and invests in its local community. This is enhanced by the quality of a university's connections, its role and outlook in knowledge production and exchange. Universities being institutions of higher learning are adequately resourced as in the form of students, academic staff, facilities, research funding, knowledge, and skills. These resources can be better utilized for community change and sustainable development 
(Hall, 2008: 4). A university's strategy would among other things, be to activate and strengthen links between local, other national and international knowledge systems.

\subsection{Background}

\subsubsection{Sustainable Development and the Botswana Context}

Botswana like most economies of the Southern African Development Community (SADC) member countries is agro-based and experiencing high levels of environmental degradation due to factors such as deforestation, loss of biodiversity, pollution, soil erosion, decreasing quality and quantity of water, poor sanitation services and urban conditions. A significant proportion of the population (47\%) in the country lives in rural areas in settlements of less than 5000 people. It is in these areas that poverty is reported to be more widespread and severe where three out of seven households cannot meet their basic needs. Statistics report of 2002/04 show the south-west (49.7\%), north-west (41.5\%) and north-east (37.8\%) as areas mostly hit by poverty.

Other challenges to sustainable development in Botswana are the accelerated growth of the rural population; for example, the rural community increased from 540,600 in 1971 to 770,400 people in 2001. In addition, a study by the Botswana Institute for Development Policy Analysis (BIDPA) in 1997 revealed that the very rain-fed agriculture that is historically one of the main economic pursuits is not yielding much to help rural poor out of poverty. Other complications include the agricultural assistance schemes and subsidies that have not been efficient and effective in targeting the deserving beneficiaries to impact positively on agricultural production (Rural Development Policy Paper 3, 2002). The eastern side of the country with the best agriculture land, higher rainfall, and more fertile soils is a growing metropolitan where more than half of the population lives; while the arid to semi-arid climate conditions: high summer temperatures, high evaporation rates, erratic rainfall, and draught continue to limit livestock, wildlife natural habitat and economic growth (USAID, 1996).

The northwest side of Botswana is the large inland delta and permanent wetland of the Okavango Delta. The central-north consists of a large area of salt pans; while, almost two thirds is covered by the Kgalagadi sands. The Okavango, rich in biodiversity, provides water and food for people, livestock, wildlife, and supports a growing tourism industry. Presently, the Okavango Delta is threatened by a growing population, expansion of livestock and opportunistic ventures by other sectors of the economy wanting to extract water at the Delta for various uses. This threatens biodiversity and sustainable use of natural resources. To address the problem of poverty and promote sustainable development, the United Nations Millennium Declaration, adopted in September, 2000, at a gathering by heads of state and governments, committed all countries rich and poor to strive to eradicate poverty, promote human dignity, equality, and achieve peace, democracy and environmental stability (UN, 2009). The Summit for Sustainability in Africa hosted by the President of the Republic of Botswana held in June 1, 2012 also came out with the "Gaborone Declaration", a new roadmap for environmentally friendly economic development. The Gaborone Declaration made by 10 African governments, the private sector and civil society institutions marked the establishment of an international movement advocating for the mainstreaming of natural capital for economic development. The Declaration comprised strategies to ensure active participation by nations in sustainable use of natural resources (Botswana Daily News report, 2012).

Other ongoing poverty reduction and eradication policies and strategies include the Revised Policy on Rural Development (2003) emphasizing improved rural livelihoods and better public services, infrastructure, employment and income creation. The Policy aims to achieve rural development through developed livestock and arable sectors, infrastructure, and encouragement of commercial activity in rural areas (BIDPA, 2001). The Strategic Framework for Community Development (2010), National Strategy on Poverty Reduction (2003), Community Based Strategy for Rural Development (1997) and the Community Based Natural Resource Management Policy (2007) add to the policy pack.

\subsubsection{The Community Based Natural Resource Management Strategy (CBNRM)}

The Botswana CBNRM is a conservation and rural development strategy whose aim since the first project in 1993 is improvement of livelihood of rural communities, the most affected by poverty. Established in 1986 by Botswana Parliament, the CBNRM was a partnership between Botswana government and the United states Agency for International Development (USAID) to set up a Natural Resource Management Project (NRMP) housed in the Department of Wildlife and National Parks (DWNP). The CBNRM approach emphasizes sustainable management of resources such as wildlife and veld products through the active participation of local communities who reside within or near Wildlife Management Areas (WMAS and Controlled Hunting Areas (CHAs). The approach uses initiatives such as community mobilization and organization, institutional development, comprehensive training, enterprise development and monitoring of the whole natural resource 
terrain. This is achieved through creation of Community Based Organizations (CBOs) or community trusts.

The activities of CBOs or trusts include collection and sale of veld products, crafts and curios, subsistence hunting or sale of hunting quota to safari companies, campsites, and processing veld foods (Kgati et al, 2002). The trusts are governed by Boards of Trustees; trusts with membership of one village fall under a Village Trust Committee (VTC) and those with more village members are governed by a Board of Trustees (ACCORD, 2002). The CBOs implement the CBNRM projects on behalf of the communities and use constitutions to regulate membership and duties of trusts, powers of Boards of Trustees and VTCs (Kgati et al, 2002). Since 1993 the number of CBOs increased from one to 46 in eight districts covering 130 villages (up to 40000 people). According to the CBNRM Status Report in 2003 the number of CBOs increased from 46 to 120.

\subsubsection{Achievements of the CBNRM}

To achieve its mandate, the CBNRM in 1998 established the Botswana Community Based Organization Network (BOCOBONET); this was to enhance coordination between CBOs and other stakeholders. Other responsibilities of BOCOBONET were dissemination of information to members, representation of member interest in policy discussion and linking them with service providers. The CBNRM also formed two forums: the North West CBNRM and the National CBNRM in 1999 to provide CBOs and other stakeholders opportunity to share experiences during conferences and meetings. The National Forum contributed significantly to the drafting of the CBNRM policy and review of a number of policies and regulations used to govern the operations of the CBOs (Jansen and Molokomme, 2003). Another achievement of the CBNRM was the policy for diversifying economy finalized in 2007. The policy's approach proved to be the most democratic way to drive development at local community levels thus, the partnerships and linkages significantly strengthening local institutions to promote sustainability (Mbaiwa, 1999).

\subsubsection{Challenges of the CBNRM Programmes}

Despite the reported achievements, the CBNRM endured challenges such as (Jones, 1999):

1) The financial support from USAID to Botswana government that could not be sustainable. This required the CBNRM to shape up and be less dependent on outside funding.

2) As CBRNM programmes became more localized, there arose the need to build local level community management institutions to manage natural resource sustainability.

3) Communities that received income from wild life and Tourism in particular had challenges in managing the resources.

4) Strong competition from other sectors for competent and experienced personnel to professionally manage CBRNM programmes became eminent and assistance needed to develop successful business partnerships.

The other challenge is what Jone (1999) calls "communtiy dynamics" or the dominance in decision-making and benefit distribtion in CBOs.

\section{The Purpose and Objectives of the Study}

The many challenges of the CBNRM as reported by Jones (1999) should not down play the policy's ability to drive development, strengthen partnerships at local community levels, and promote sustainability (Mbaiwa, 1999). University of Botswana (UB) should be a robust contender in the partnerships to play a more impactful role in the successful implementation of the CBNRM programmes to enhance sustainable development in Botswana. The purpose of the study was to identify the roles that UB can play in sustainable development of rural communities in Botswana and to determine whether the university had the necessary engagement capacity to facilitate implementation of sustainable development programmes. The specific objectives of the paper were firstly, to review community engagement practice at UB and determine its strength in making the university more impactful in sustainable development programs for rural communities; and secondly, to identify engagement models to guide best practice by the university to promote sustainable development in rural communities.

\section{Methodology}

The study adopted a qualitative research approach using document analysis to interpret data. Documents contain data recorded in text; document analysis therefore enables researchers to examine variety of written material relevant to the phenomenon under study, and interpret data to develop empirical knowledge (Corbin and Strauss, 2008). Document analysis uses systematic procedure to identify, select, appraise the documents and synthesize data. The study therefore relied on content analysis of published and unpublished documents including Botswana government reports, University of Botswana (UB) policy reports, conference proceedings, journal articles, 
newspapers, informal discussions with advisory committees and public records.

\section{Theoretical Framework and Related Concepts}

The greatest problems of sustainability are associated to human relationships with the environment and activities by diverse populations of the world. This requires an articulated and relevant theoretical perspective to understand the role of the main actors in sustainable development, their activities and value added to the environment. Systems theory provides a methodology for studying relationships, the interdependence, networks, and connectedness of elements. Such elements make a complex system where a change in one often leads to unpredictable changes in others (Pappas, 2012). Systems theory posits that people exist as members of social groups or a social system within an environment comprising diverse systems. The members of such social systems play different roles in the systems that impact on one another (Parsons, 1977).

As noted by Pappas, solutions to sustainability problems require an understanding of human consciousness, the origin and importance of the values associated with the act by an individual. For instance, according to Pappas (2012), natural and industrial factors are not the only causes of environmental and social degradation; human intention and action can create and also solve sustainability problems. These are some of the activities that the Community Based Natural Resource Management (CBNRM) strategy aims to curb. Systems theory therefore, helped demonstrate UB's role as a catalyst in sustainable development of rural communities in Botswana.

\subsection{Sustainable Development and University Community Engagement}

\subsubsection{Sustainability}

Sustainability as a concept denotes multiple disciplines, different actors, and therefore different roles played by actors in development. Sustainability emphasizes active engagement of community members in their own well-being to meet their own needs, express their greatest potential while preserving the environment. When people individually or collectively apply their skills to maintain the long-term productivity of the natural resources on which they depend, sustainability succeeds (Pappas, 2012). Sustainability in this case is seen as a property of the ecosystem and associated environmental issues, global warming, climate change, and conservation practices. Universities have a special role as innovators in the practice of sustainability and therefore, have to broaden their engagement agendas to complement national sustainable development efforts (Renner and Cross, 2008; Bridger and Alter, 2006). The Graz Declaration (2005) recognized this important role of universities and called on the institutions to use their mandates of teaching, research and especially, the third mission, namely, community engagement to uphold the status of sustainable development.

Sustainability practice must focus on all critical system levels: the individual community member, household, local community, stakeholder, and institutional levels. The principle of sustainability implies that systems must be maintained; resources ought to be used only at the rate at which they can be replenished (Pappas, 2012). According to Ife and Tesoriero (2006) community development actually represents the vision of how things might be organized differently so that sustainability can be realized. This is by maintaining a balance between economic growth and development of human and social capital where all dimensions of community livelihood, social, economic, political, environmental are addressed (Kingsbury et al., 2008).

Sustainable community development can be seen from other perspectives such as human social dynamics, activities, organization, and practices including community building or social transformation. Social transformation is responsible for the re-construction of social, cultural and economic relationships through processes of social action such as self-evaluation, self-assertion, self-reliance, and self-determination, particularly, by the powerless and marginalized groups (Chile, 2004). Therefore, active local participation is crucial to ensure a development process that has the community buy in. According to Roling and Pretty (FAO, pg 3), sustainability is attained when people understand "what is to be sustained, for how long, for whose benefit and at whose cost": that is the gap universities as innovators of sustainable development must close to play their role. In fact, the knowledge-based partnerships by universities and communities use a research approach that emphasizes the very multi-disciplinary collaboration and community building under which sustainable development thrives; while, at the community level, the pre-requisite for successful sustainable development is a vision, strategy and a plan.

\subsubsection{Community Engagement}

Different meanings of community engagement have been documented. These include Community engagement as a partnership between the university and local people to facilitate community interaction for the individual and social well-being. This happens through direct interaction by a learning institution with its external environment through a mutual exchange, exploration, and application of knowledge, skills and information 
(Delaforce, 2004). Community engagement is the process by which universities in their localities, establish partnerships with communities (internal) that are within the locality and those outside (external). The partnership between the university and the community ought to be mutually beneficial for it to pass as community engagement (Langworthy, 2003).

Bridger and Alter (2006), in their discussion of the Interactional Approach to Community (IAC) argue that for universities to effectively address concerns of social responsibility close ties with the real problems of people in the community must be kept. This can be accomplished through community engagement approach that holds a realistic concept of community. The IAC, despite the change of community character over time, sees social interaction as an integral feature that gives structure to locale life. Social interaction is seen to delineate a "territory as the community locale; it provides the associations that comprise the local society; it gives structure and direction to processes of collective action; and it is the source of community identity" (Bridger and Alter, 2006). That view of community as Bridger and Alter (2006: 170) suggest, defines university community engagement as a 'unique model'. That is, the university working in partnership with local people to facilitate a wide range of community interaction to enhance individual and social well-being. In this case the interactions enrich and expand the teaching and research functions of a university; partnerships are strengthened and capacity of community is enhanced. However, for university engagement to be more directed its purpose should be clear as to whether the agenda aims at 'development in the community', a top-down process including activities such as job creation, business retention, and employee training initiatives; or, 'development of the community', a broader and bottom-up process occurring because of the interaction of local community members with one another on projects and issues that build networks across groups and interest groups (Holland, 2001).

The literature on university-community engagement offers many models and a wide variety of frameworks for engagement to maximize mutual benefit. Examples of such frameworks can be deduced from four dimensions of sustainability (Renner and Cross, 2008): 'care and concern for the environment', 'partnership and collaboration to achieve sustainability', 'stewardship for sustainability', and 'management to achieve sustainability'. Table 1 shows the dimensions and possible areas of engagement by universities (Renner and Cross, 2008) while table 2 illustrates four modes of university engagement for sustainable development (Wallis et al., 2005).

Table 1. Sustainability Dimensions and Areas of University Community Engagement

\begin{tabular}{|c|c|c|c|c|}
\hline $\begin{array}{l}\text { Care \& Concern for } \\
\text { the Environment }\end{array}$ & $\begin{array}{l}\text { Partnership } \\
\text { Collaboration } \\
\text { Sustainability }\end{array}$ & $\begin{array}{r}\& \\
\text { for }\end{array}$ & $\begin{array}{l}\text { Stewardship } \\
\text { Sustainability }\end{array}$ & $\begin{array}{l}\text { Management to } \\
\text { Achieve Sustainability }\end{array}$ \\
\hline 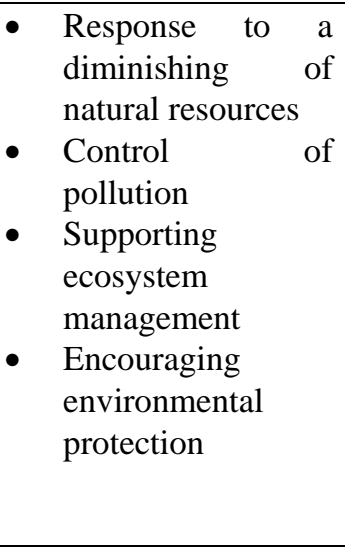 & $\begin{array}{ll}\text { - } & \text { Working in teams } \\
\text { - } & \text { Planning } \\
\text { long-term } & \text { development } \\
\text { - } & \text { Committing } \\
\text { environmental goal } \\
\text { - } & \text { Building } \\
\text { achievements } \\
\text { - Sharing } \\
\text { communicating } \\
\text { Sustainable } \\
\text { development } \\
\text { others } \\
\end{array}$ & $\begin{array}{l}\text { for } \\
\text { to } \\
\text { on } \\
\text { and }\end{array}$ & $\begin{array}{l}\text { - } \text { Avoiding waste } \\
\text { - } \text { Recycling and } \\
\text { re-use of materials } \\
\text { - Using clean } \\
\text { technologies for } \\
\text { production } \\
\text { - Monitoring any } \\
\text { degrading of the } \\
\text { local environment }\end{array}$ & 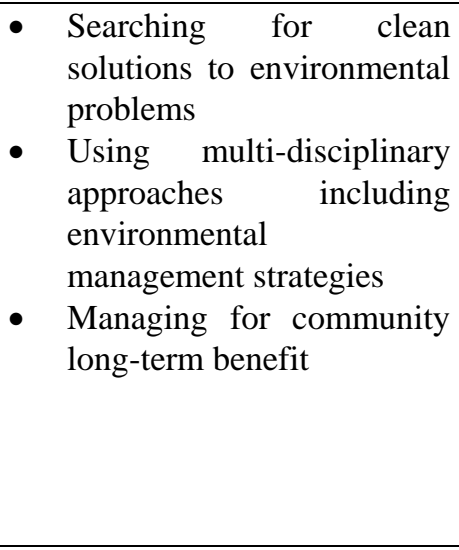 \\
\hline
\end{tabular}

Table 1 adapted from Renner and Cross (2008: 389)

According to Wallis et al. (2005) universities can engage with communities in four ways to promote sustainable development. These are engagement through 'best practice in sustainability', 'producing graduates who are skilled and committed to sustainability', 'research committed to sustainability', and lastly, engagement through 'sustainability partnerships'. Table 2 shows the four modes through which a university can engage with communities to promote sustainable development as recommended by Wallis et al. (2005). 
Table 2. Sustainable Development University Engagement Model

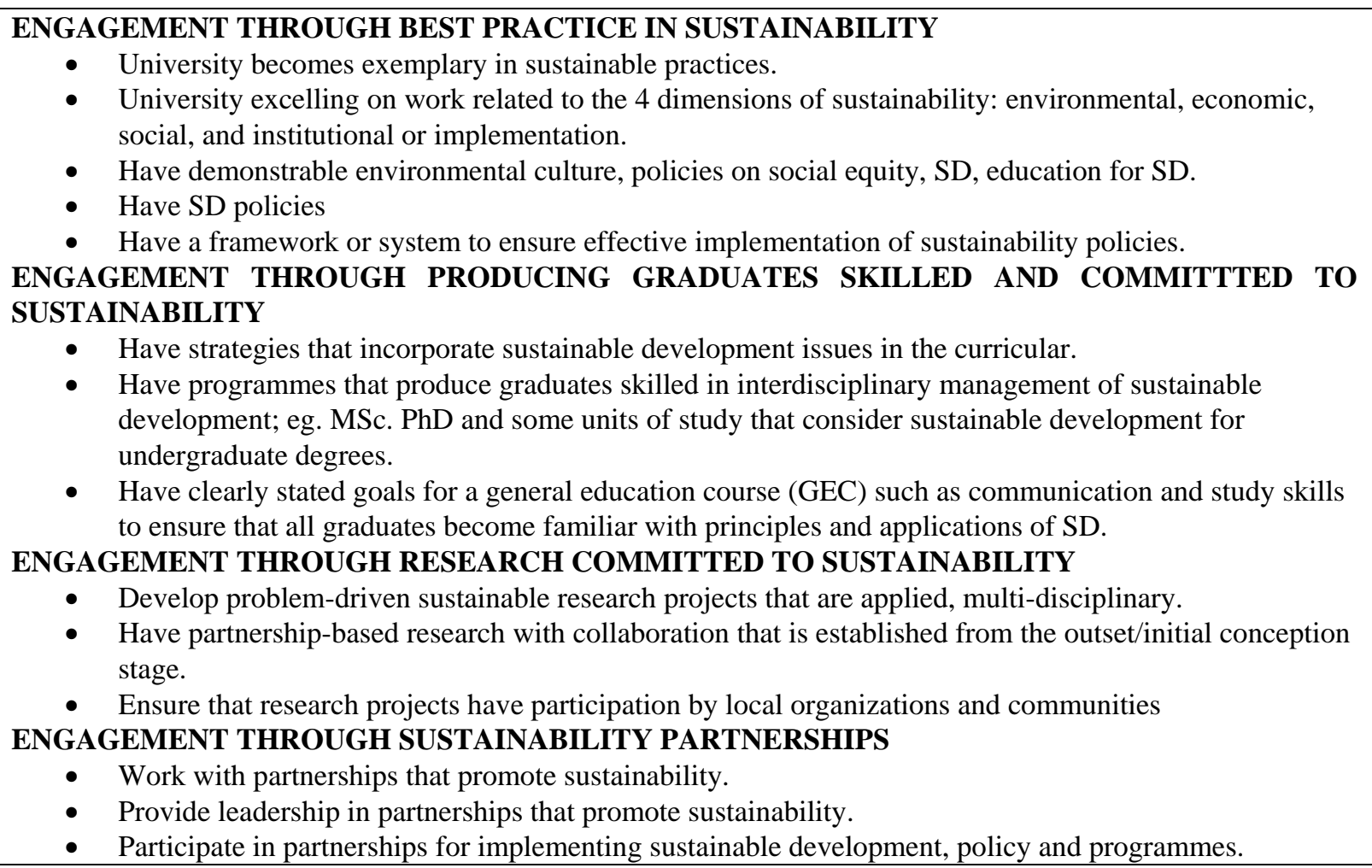
Table 2 adapted from Wallis R. L., Wallis A. M. \& Harris C. M. (2005: 4-7)

A university choosing to engage through best sustainability practice has to excel, for instance, in the generation of knowledge, skills in certain aspects of the environment, have the financial support and be economically self-sufficient and able to afford sustainable practices; where the university does not have already established programmes, it can develop relevant curricula to produce graduates skilled in the interdisciplinary management of sustainable development. Recommendation for standardized natural resource monitoring system and capacity building of communities, and capacity building of support organizations should benefit from the university through skilled graduates and expansion of student attachment programmes. This is a gain for students and a university as well.

\section{Discussion}

\subsection{The Status of Community Engagement at the University of Botswana}

Historically, university engagement with the community was one-sided, often embraced under traditional umbrella of extension, outreach and, or community service (Shanon and Wang, 2010). Engagement aimed at gaining access to research sites, internship, and extension of expertise (Bridger and Alter, 2006). In the case of the UB, the Centre for Continuing Education was mandated since 1991 to direct and coordinate extension and outreach programmes on behalf of the University. Other outreach activities were run by various faculties and individual academic personnel research and consultancy projects. Community service was understood to be about the "extension of the University expertise to the world outside the university, the community, in the service of improving quality of life of the community and which is effected through a university model in which community service is integral to all aspects of the university: mission, structure and organization, hiring and promotion, curriculum and teaching, research and publication" (Lulat, 2005: 262).

The University of Botswana's commitment to community service is a welcome development and invaluable contribution to sustainable development. The UB Strategic Plan 2016 and Beyond outlines six priority areas, one of which is that of strengthening engagement. In addition, in 2009, the UB entered into a two-year partnership with PASCAL International Observatory PURE Project. A Memorandum of Understanding (MoU) was signed in April 2009 allowing the UB a two year participation in the PURE research project. PASCAL International Observatory (PASCAL) is an independent non-profit-making consultancy on Regional Development and an extension of the Organization for Economic Cooperation and Development (OECD) work of the late nineties. It 
was founded following an International OECD Conference held in Melbourne in 2002.

The PASCAL Universities Regional Engagement (PURE) is a project representing previous work extended to new regions by PASCAL International Observatory (PASCAL). The aim of the PURE project is to help universities to identify policy initiatives for more effective engagement with regions, external environment or community. Region according to PURE refers to any locality; that is a large metropolitan; an area demographically mixed with large populations or thinly populated and economically fragile. The area could be far from or peripheral to major population centres (Duke, 2010).

From 2009 to 2010, the PURE project explored two issues: how higher education institutions engaged with the community to enhance economic, social and cultural development. The PURE research project began usually by:

- firstly, learning more about the issues of development in the regions and the contribution by universities to the issues; and,

- secondly, understanding more the governing structures within the regions; that is the management of universities and regions and how the two engaged. This was in recognision of the differenct national policy contexts of regions and universities and the often competing missions of universities.

To assist members, PURE provided expertise through on-line cluster discussions, conferences, benchmarking tools, and visits by PASCAL technical group from the University of Glasgow. Regional universities used bench marking tools to assess their engagement agendas.

In Botswana PURE work began with a partnership with Gaborone City (GC) formalized by a Memorandum of Understanding signed in September 2010. A PURE research committee comprising representatives of the UB and GC conducted a needs assessment study. The data was to inform engagement in five focus areas of culture, environmental sustainability, physical planning and economic empowerment. Results of the needs assessment, especially with regard to sustainable development showed a weak, uncoordinated collaboration between the UB and the city of Gaborone. Modalities and logistics for facilitating collaboration were found weak hence a more permanent framework or structure was recommended for a beneficial partnership between the University, Gaborone City and other communities (Gwebu, 2010). The results therefore led to the development of a draft strategic plan to guide future engagement by UB.

\subsection{Engagement Model Proposed for the University of Botswana}

The present study recommends a framework with a mix of features by Holland and Ramsey (2008), Bridger and Alter (2010), and those for sustainable development by Wallis et al. (2005), and Renner and Cross (2008). The framework should re-position community engagement at UB as a coordination and more organized practice to enable the University to be a more impactful partner in the implementation of the CBNRM and sustainable development. Table 3, 4, 5, and 6 adapted from the Wallis et al, (2005) model demonstrate four ways in which the UB can engage with its communities to promote sustainable development (SD).

Table 3. UB Engagement and Best Practice in Sustainability

\section{ENGAGEMENT THROUGH BEST PRACTICE IN SUSTAINABILITY}

- Being exemplary in sustainable practices: since a draft strategy for CE developed (after needs assessment study using an adapted PURE benchmarking tool) in 2010 exists, start by finalizing the strategy.

- Excelling on work related to the 4 dimensions of sustainability: after finalizing engagemen t strategy, identify SD dimensions that UB is excelling in and translate those into strategic goals to drive CE programs before CE/ SD policy is developed.

- Have demonstrable environmental culture, policies on social equity, SD, education for SD: develop policy for SD with policy objectives for SD education including capacity building for the public.

- Have SD policies: finalize SD and CE policies.

- Have a framework or system to ensure effective implementation of sustainability policies: SD and CE policies once they exist, they should provide the framework or system.

As demonstrated on Table 3, engagement through best practice requires finalization of the draft strategy and policy for community engagement. Once the University has an engagement strategy, thematic areas for sustainable development can be chosen; more programmes can be developed and implemented even before a policy for community engagement is drafted. For instance, one of the recommendations for successful implementation of the CBNRM sees as crucial the introduction of Community Based Organizations (CBOs) mentoring programme (CBNRM Forum Discussion Paper, 2005). The UB "Strategic Plan 2016 and Beyond" 
emphasizes strengthening engagement through collaboration of relevant faculties and departments. That collaboration could provide the mentoring required by the CBOs, while sharing other practices for the successful implementation of the programmes of the CBNRM.

Table 4. UB Engagement and Production of Skilled and Committed Graduates

\section{ENGAGEMENT THROUGH PRODUCING GRADUATES SKILLED AND COMMITTTED TO SUSTAINABILITY}

- Have strategies that incorporate SD issues in curricular: this should be taken care of by SD and CE policies once they are in place.

- Have programmes that produce graduates skilled in interdisciplinary management of sustainable development; eg. MSc. PhD and some units of study that consider sustainable development for undergraduate degrees: there is some integration of SD in the UB curricular; but once strategies for integration of SD in UB curricular are finalized, more programs should be developed in various faculties.

- Have clearly stated goals to incorporate SD units of study in undergraduate degree programs: could have a general education course (GEC) such as communication and study skills to ensure that all graduates become familiar with principles and applications of SD. Could start by piloting the GEC with undergraduate programs in faculties that are closely related to issues of SD such Faculties of Education, Business, Science, Engineering and Technology, and short courses at the Centre for Continuing Education.

Table four shows UB engaging through skilled and committed graduates at three levels. Firstly, the University needs strategies that advocate for the integration of sustainable development issues in all faculty curricula for graduate and undergraduate degree programmes. Some faculties do have undergraduate degree programmes that offer combinations with environmental studies, such as the degree in Economics and Environmental Science of the faculty of Social Sciences (UB Prospectus, 2010). Recommendations 4, 2 (a) and (b), for "standardized natural resource monitoring system, and capacity building of communities and of support organizations" (CBNRM Discussion Paper, 2005) suggest an engagement gap of the UB in the CBNRM. The University through graduate internship and attachment programmes should supply the relevant skills required and in turn students gain real field-based experience, appreciation of rural community life and livelihood strategies used that impact on the environment. Experiences from the field are an asset for improving curricula.

Table 5. UB Engagement Through Research

\section{ENGAGEMENT THROUGH RESEARCH COMMITTED TO SUSTAINABILITY}

- Develop problem-driven sustainable research projects that are applied, multi-disciplinary: as a CE strategy participate in community/rural development fora and through interaction at all community field levels, identify problems/research needs. Liaise with the Department of Research and Development, other research partners to promote more SD related research through eg. Funding of Msc/PhD research and giving priority to academic staff research projects that are SD related and problem-driven.

- Have partnership-based research: adopt a transdisciplinary approach to research (Hendrickson, 2005) to encourage a more holistic research collaboration with community partners arround any combination of sustainability topics.

- Ensure that research projects have participation by local organizations and communities: UB has a number of on-going research projects with local organizations and communities. Collaboration must be by equal partners not the UB playing the role of researcher (superior) and other partners as the researched.

The UB academic staff does research in a wide range of subject areas. Research partnerships can be established with community organizations, communities, and other stakeholders to carry out community problem-driven studies that can further improve performance of CBOs and the implementation of the CBNRM programmes. 
Table 6. UB Engagement and Sustainability Partnerships

\section{ENGAGEMENT THROUGH SUSTAINABILITY PARTNERSHIPS}

- Work with partnerships that promote sustainability: active participation in the CBNRM and related programs. Identify engagement gaps in the CBNRM and develop partnerships according to thematic areas of the UB/SD policy once developed.

- Provide leadership in partnerships that promote sustainability: participation as member in higher decision-making fora such as the CBNRM Forum.

- Participate in partnerships for implementing SD, policy and programs: active participation in the implementation of the CBNRM.

- Need activities beyond conference attendence and individual staff research consultancies but a holistic collaboration plan in place; eg. Capacity building for CBOs: ie. Through training of CBO members, training of extension staff who work with and advise $\mathrm{CBO}$, $\mathrm{CBO}$ problem-driven research projects, sourcing funding through UB partnerships to support $\mathrm{CBO}$ s, mentoring of $\mathrm{CBO}$ s and CBNRM advisory committees. Providing legal advice through the UB legal Clinic, for example.

Engaging through sustainability partnerships requires the UB to first identify sustainability issues of national concern and then find subject areas to pattern engagement messages into. Other partnership opportunities are in the implementation of sustainable development policies. In the case of the CBNRM Forum, the UB could secure membership in the CBNRM Forum at both the District and National levels and collaborate with other organizations in providing the leadership required. The responsibilities of the Forum cover a number of responsibilities that are within the mandate of the University.

Table seven shows specific areas of UB engagement according to the objectives of the CBNRM Policy to further demonstrate the need for the University as a role player in sustainable development of rural communities. 
Table 7. UB Engagement Focus Areas and Implementation of the CBNRM Programmes

\begin{tabular}{|c|c|c|c|c|}
\hline \multirow{2}{*}{$\begin{array}{l}\text { CBNRM POLICY } \\
\text { OBJECTIVES }\end{array}$} & \multicolumn{4}{|c|}{ SUSTAINABLE DEVELOPMENT UNIVERSITY ENGAGEMENT MODES } \\
\hline & Best Practice & Producing Skilled Graduates & $\begin{array}{l}\text { Research in } \\
\text { Sustainability }\end{array}$ & $\begin{array}{l}\text { Sustainability } \\
\text { Partnerships }\end{array}$ \\
\hline $\begin{array}{l}\text { Specify community } \\
\text { natural resource user } \\
\text { conditions }\end{array}$ & & & $\begin{array}{l}\text { Make inventory of } \\
\text { natural resources } \\
\text { according to districts. } \\
\text { Participatory research to } \\
\text { find out different use of } \\
\text { natural resources by } \\
\text { communities. } \\
\text { Study the various } \\
\text { external environment or } \\
\text { vulnerability contexts of } \\
\text { communities. } \\
\text { Community needs } \\
\text { assessment, information } \\
\text { about how people make a } \\
\text { living: assets, income, } \\
\text { household food, etc }\end{array}$ & $\begin{array}{l}\text { Maintain close ties with the } \\
\text { communities \& CBO's. } \\
\text { Identify engagement gaps } \\
\text { to drive the objective \& } \\
\text { develop partnerships with } \\
\text { existing CBNRM } \\
\text { structures. }\end{array}$ \\
\hline $\begin{array}{lr}\text { Provide an incentive } \\
\text { structure } & \text { for } \\
\text { conservation \& natural } \\
\text { resource management }\end{array}$ & $\begin{array}{l}\text { Benchmark with } \\
\text { other institutions. }\end{array}$ & & & $\begin{array}{l}\text { Identify engagement gaps } \\
\text { to drive the objectives \& } \\
\text { develop partnerships with } \\
\text { existing } \\
\text { structures \& } \quad \text { CBNRM } \\
\text { stakeholders. }\end{array}$ \\
\hline $\begin{array}{l}\text { Create opportunities for } \\
\text { community participation } \\
\text { in natural resource } \\
\text { management } \\
\text { monitoring }\end{array}$ & & $\begin{array}{l}\text { Attachment of students to } \\
\text { relevant CBOs: students share } \\
\text { expertise \& learn at the same } \\
\text { time through } \\
\text { practice/experience. } \\
\text { Develop relevant training. }\end{array}$ & & $\begin{array}{l}\text { Identify engagement gaps } \\
\text { to drive the objective \& } \\
\text { develop partnerships with } \\
\text { exiting CBNRM structures. }\end{array}$ \\
\hline $\begin{array}{l}\text { Facilitate capacity } \\
\text { building in natural } \\
\text { resources-based tourism }\end{array}$ & & $\begin{array}{l}\text { Attachment of students to } \\
\text { relevant CBOs: students share } \\
\text { expertise \& learn at the same } \\
\text { time through } \\
\text { practice/experience }\end{array}$ & $\begin{array}{l}\text { CBO member training } \\
\text { needs assessment: all } \\
\text { levels, support groups, } \\
\text { eg. } \\
\text { staff/extension workers }\end{array}$ & $\begin{array}{l}\text { develop partnerships with } \\
\text { exiting CBNRM structures } \\
\text { to provide training }\end{array}$ \\
\hline $\begin{array}{l}\text { Establish an institutional } \\
\text { framework for the } \\
\text { implementation of } \\
\text { CBNRM }\end{array}$ & $\begin{array}{l}\text { Recommend best } \\
\text { frameworks, \& } \\
\text { provide technical } \\
\text { support. }\end{array}$ & & & $\begin{array}{l}\text { Identify engagement gaps } \\
\text { to drive the objective \& } \\
\text { develop partnerships with } \\
\text { exiting CBNRM structures. }\end{array}$ \\
\hline
\end{tabular}

To contribute to the successful implementation of the policy, content and thematic analysis of the objectives shows UB engaging mostly through "sustainability partnerships" followed by "research committed to sustainability".

\section{Conclusion}

The purpose of the study was to identify the roles that UB can play in sustainable development of rural communities in Botswana and to determine whether the university had the necessary engagement capacity to facilitate implementation of sustainable development programmes. The spread of poverty with highest incidences reported in the rural parts of the country, and the UB regarded as a key innovator in the national development efforts are all environmental circumstances that challenge the University to extent coverage of its community engagement beyond Gaborone City in order to engage more closely with rural communities whose livelihood depend on the very natural resources that need sustainability (Buzwani, 2006). As stated by the late 
Sir Seretse Khama, President of the Republic and Chancellor of the then University of Botswana and Swaziland in his graduation speech of May 1970: the University must be committed to the "fulfillment of the ambitions and aspirations of the communities it was created to serve"

(http://www,.sarua.org/?q=content/university-botswana-history).

The paper has confirmed that the CBNRM in Botswana is a good initiative for sustainable development. In particular, the Botswana CBNRM strategy focuses on providing incentives for communities to take responsibility for managing natural resources sustainably and building community capacity to do this. The National Conservation Policy and Legislation affecting CBNRM programmes contain general references to promoting greater involvement of rural people in conservation through education and employment creation. This is an important opportunity for the University of Botswana to use its resource, academics and students to educate rural people.

The study further proposed a model with four engagement options for sustainability. These were engagement through: (a) best practice, (b) producing graduates strong in sustainability skills, (c) research committed to sustainability, and (d), sustainability partnerships. To contribute to the successful implementation of the CBNRM content analysis of the CBNRM draft policy objectives showed the focus of the UB community engagement needed on two modes: "sustainability partnerships" and "research committed to sustainability".

\section{References}

ACCORD, (2002). Through our eyes: ACCORD's experience in CBNRM. Agency for Cooperation and Research in Development. Unpublished article, Okavango Community Trust Gumare, Botswana.

Artzen, J. W. (2003). Final report of the review of Community Based Natural Research Management in Botswana. Report by the Center of Applied Research for National CBNRM Forum.

Atterton, J., \& Thompson, N. (2010). University engagement in rural development: a case study of the Northern Rural Network. Journal of Rural and Community Development, 5(3), 123-132.

Batanovic, V., Guberinic, S., \& Petrovic, R. (2011). Systems theoretic approaches to sustainable development problems. Yogoslavia Journal of Operations Research, 21(1), 1-10. https://doi.org/10.2298/YJOR1101001B

Bridger, J. C., \& Alter, T. R. (2006). The engaged university, community development and public scholarship. Journal of Higher Education, Outreach and Engagement, 11(1), 163-178.

Buzwani, B. (2006). Economic value of the okavango delta. Botswana Report to INCN-Botswana. The Department of Environmental Affairs, Gaborone: Botswana.

Chile, L. M. (2004). Good community development practice: An instrument for building community and development society. Keynote Address, New Zealand Council of Social Services Conference, Hamilton Gardens Pavilion.

Corbin, J., \& Strauss, A. (2008). Basics of qualitative research: Techniques and procedures for developing grounded theory (3rd ed.), Thousand Oaks, CA: Sage. https://doi.org/10.4135/9781452230153

Delaforce, W. (2004). Building community university engagement: a program theory approach. Paper Presented to the Social Change in the $21^{\text {st }}$ Century Conference. Centre for Social Change Research. Queensland University of Technology.

Duke, C. (2003). University regional provisiont owards a new art of engagement. B-Hert News, 17, 1-4.

Gwebu, T. (2010). The level of engagement between the University of Botswana and Gaborone City region stakeholders in promoting sustainable environmental development. Paper presented at PASCAL/PURE Conference, University of Botswana, Gaborone.

Hall, B. L. (2009). Higher education, community engagement and public good: building the future of continuing education in Canada. Canadian Journal University Continuing Education, 35(1), 11-23. https://doi.org/10.21225/D5BC7N

Holland, B. A. (2005). The growing role of community engagement in the US higher education. B-HERT, 21, $2-4$.

Ife, T., \& Tesoriero, F. (2006). Community development: community-based alternatives in an age of globalization $\left(3^{\text {rd }}\right.$ ed). Australia: Pearson Education.

Jansen, R., \& Molokomme, K. (2003). Mid-Term Review Report of the German Development Service (DED) Natural Resources Management Programme in Botswana. 
Jones, B. T. B (1999). Community-Based Natural Resources Management in Botswana and Namibia: An inventory and preliminary analysis of progress. Report presented to IIED in 1997 and published in 1999.

Kende-Robb, C. (2016). Powering the sustainable development goals in Africa: rewriting the global rules. Retrieved from www.huffington post.com/caroline-knderobb/powering-the-sustainable_b_12100052.html

Kgati, D. L., Mbaiwa, J. E., \& Motsholapheko, M. (2002). Local institutions and natural resource management in Ngamiland. Harry Oppenheimer Okavango Research Centre, University of Botswana, Maun.

Khama, S. S. (1970). University of Botswana, Lesotho and Swaziland Graduation Speech: Botswana Daily News, 19 May 1970. Retrieved from www.ub.bw/content/id/1366/History/

Kimball, M., \& Thomas, D. (2012). Place-Building Theory: framework for assessing and advancing community engagement in higher education. The Applied Anthropologist, 25(2), 125-130.

Kingsbury, D., McKay, J., Hunt, J., McGillivray, M., \& Clarke, M. (2008). Introduction in International Development Issues and Challenges, eds. Palgrave Macmillan.

Langworthy, A. (2003). New models of community partnership: pitfalls and promises. Second Biennial Inside Out Conference on Higher Education and Community Engagement, Ipswich, Queensland, 3-5 July. Retrieved from http://www.uq.edu.au/insideout/pdfs/annelang.pdf

Lulat, Y. G. (2005). A history of African higher education from antiquity to the present. Santa Barbara, CA: Greenwood Publishing Group.

Mbaiwa, J. E. (1999). Prospects for sustainable wildlife resource utilisation and management in Botswana: a case study of East Ngamiland District. unpublished M.Sc. Thesis. Department of Environmental Science, University of Botswana, Gaborone.

National CBNRM Forum Discussion Paper, (2005). Gaborone, Botswana: Government Printers.

National CBNRM Forum Discussion Paper (2006). Gaborone, Botswana: Government Printers.

Pappas, E. (2012). A New Systems Approach to Sustainability:University Responsibility for Teaching Sustainability in Contexts. Journal of Sustainability Education, 3. Retrieved from http://www.susted.org/

Payne (1997 in Chile, 2004). Good Community Development Practice: An Instrument for Building Community and Development Society. Keynote Address, New Zealand Council of Social Services Conference, Hamilton Gardens Pavilion.

Renner, J., \& Cross, J. (2008). Community Engagement for Sustainability: an invitation and challenge to all universities. Edu - com 2008 International Conference. Edith Cowan University, Perth, Australia, November, 2008. Available at Research online. Retrieved from http://ro.ecu.edu.au/edu.au/ceducom/37

Republic of Botswana, (Vision 2016). A long term development strategy. Botswana: Government Printers.

Republic of Botswana, (2012). Gaborone Declaration, Inside the Presidency Weekly Update, Botswana Daily News Report. The Daily News Paper, No. 103.

Republic of Botswana (2010). Gaborone City $(G C)$ and the University of Botswana. Memorandum of Understanding, September, 2010.

Republic of Botswana (2010). Strategic Framework for Community Development in Botswana. Ministry of Local Governments/European Development Fund: Gaborone, Botswana.

Republic of Botswana (2007). Community Based Natural Resource Management Policy. Botswana: Government Printers.

Republic of Botswana (2003). National Strategy on Poverty Reduction. Botswana: Government Printer.

Republic of Botswana (2003). Revised National Policy on Rural Development. Gaborone: Government Printers.

Republic of Botswana (2002). Revised National Policy for Rural Development Policy. Paper 3. Gaborone.

Republic of Botswana (1997). Community Based Strategy for Rural Development. Botswana: Government Printer.

Republic of Botswana Institute for Development Policy Analysis (BIDPA, 1997). Government Paper. Gaborone, Botswana: Government Printers.

Revised Rural Development Policy, (2002). Gaborone, Botswana: Government Printers.

Roling, N., \& Pretty, J. Improving Agricultural Extension, A reference manual. Chapter 20, Extension's Role in 
Sustainable Agricultural Development. FAO. Retrieved from www.fao.org/docrep/W5830E/w5830oeOm

Shanon, J., \& Wang, T. R. (2010). A Model for University-Community Engagement: Continuing Education's Role as Convener. Journal of Continuing Higher Education, 58(2), 108-112. https://doi.org/10.1080/07377361003661499

Schiele, J. J. (2005). Meaningful Involvement of Munisipal Purchasing Departments in Procurement of Consulting Services: Case studies from Antario, Canada. Journal of Purchasing and Supply Management, 1, 14-27. https://doi.org/10.1016/j.pursup.2005.04.001

Sir, S. K. (1970). Graduation Speech by the President of the Republic of Botswna and Chancellor of the University of Botswana. Retrieved from http://www,.sarua.org/?q=content/university-botswana-history

The Graz Declaration (2005). Retrieved from www.uni-graz.at/sustainability/Graz_Declaration

USAID, (1996). Final Evaluation of the Botswana Natural Resources Management Project. United States agency for International Development. Gaborone.

University of Botswana Prospectus, (2010). University of Botswana: Gaborone.

University of Botswana "Strategic Plan 2016 and Beyond". University of Botswana: Gaborone.

United Nations Millennium Declaration, adopted in September, 2000.UN, (2009). Rethinking Poverty. Retrieved from www.un.org/esa/socdev/rwss/docs/2010/fullreport.pdf

Wallis, R., Wallis, A. M., \& Harris, C. M. (2005). How Universities Can Enhance Sustainable Development Through Successful Engagement with their Regional Communities. Retrieved from http://www.engagingcommunities2005.org/abstracts/Wallis-Robert-final.pdf

Bridger, J., \& Alter, T. (2006). The Engaged University, Community Development and Public Scholarship. Journal of Higher Education, Outreach and Engagement, 11(1), 163-178.

\section{Copyrights}

Copyright for this article is retained by the author(s), with first publication rights granted to the journal.

This is an open-access article distributed under the terms and conditions of the Creative Commons Attribution license (http://creativecommons.org/licenses/by/3.0/). 